\title{
First description of the male of Lepthyphantes lagodekbensis Tanasevitch, 1990 (Arachnida: Aranei: Micronetinae)
}

\section{Первоописание самџа Lepthyphantes lagodekbensis Tanasevitch, 1990 (Arachnida: Aranei: Micronetinae)}

\author{
Stefan Otto ${ }^{1}$, Andrei V. Tanasevitch ${ }^{2}$ \\ С. Отто ${ }^{1}$, А.В. Танасевич ${ }^{2}$
}

\begin{abstract}
${ }^{1}$ University Wuerzburg, Department of Animal Ecology and Tropical Ecology, Biocenter Am Hubland, 97074 Wuerzburg Germany. Email: s.otto_bio@gmx.net.

'Университет г. Вюрцбург, отделение экологии животных и тропической экологии, Вюрцбург 97074 Германия.

${ }^{2}$ Centre for Forest Ecology and Production, Russian Academy of Sciences, Profsoyuznaya Str. 84/32, Moscow 117997 Russia. E-mail: and-tan@mail.ru.

${ }^{2} Ц$ ентр по проблемам экологии и продуктивности лесов РАН, Профсоюзная ул. 84/32, Москва 117997 Россия.
\end{abstract}

KEY WORDS: Spiders, Linyphiidae, Lepthyphantes, Bolyphantes, new combination, Caucasus, Georgia.

КЛЮЧЕВЫЕ СЛОВА: Пауки, Linyphiidae, Lepthyphantes, Bolyphantes, новая комбинация, Кавказ, Грузия.

ABSTRACT. The male of Lepthyphantes lagodekhensis Tanasevitch, 1990 is described from Georgia (Caucasus) for the first time. The examination of the genital organs of both sexes showed the species actually belongs to Bolyphantes C.L. Koch, 1837, and most similar to the South Siberian B. distichus (Tanasevitch, 1986) and B. distichoides Tanasevitch, 2000.

РЕЗЮМЕ. Впервые описан самец Lepthyphantes lagodekhensis Tanasevitch, 1990 из Грузии. Изучение гениталий представителей обоих полов позволило установить, что данный вид в действительности относится в роду Bolyphantes C.L. Koch, 1837 и наиболее близок к южносибирским B. distichus (Tanasevitch, 1986) и $B$. distichoides Tanasevitch, 2000.

\section{Introduction}

Lepthyphantes lagodekhensis Tanasevitch, 1990 has been described from high altitudes of the Lagodekhi Nature Reserve (nowadays Lagodekhi National Park), Caucasus, Georgia, from two females [Tanasevitch, 1990]. In the absence of the conspecific male, this species was wrongly identified as a Lepthyphantes Menge, 1866 representative. New material from Khevsureti, Georgia, containing one male and seven females of L. lagodekhensis, allowed revealing that this species actually belongs to Bolyphantes C.L. Koch, 1837.

The present paper is devoted to the first description of the male and the short redescription of the female of L. lagodekhensis.

\section{Material and Methods}

This paper is based on the spider material collected by Stefan Otto in 2007 in Khevsureti region, Georgia (Caucasus Major). The material is deposited in the Berlin Museum of Natural History (coll. No. ZMB 48391).

In the description, the chaetotaxy is given in a formula, e.g., 2-1-0-2(3), meaning that tibia I has two dorsal spines, one pro-, no retrolateral spine, and two or three ventral spines (the apical spines are disregarded). All measurements are given in $\mathrm{mm}$. All scale lines in the figures correspond to $0.1 \mathrm{~mm}$.

The terminology of the genital structures follows Saaristo \& Tanasevitch [1996].

Abbreviations used in the text and figures: DS distal part of scape, EP — embolus proper, $\mathrm{Fe}$ femur, L - lamella characteristica, LL - lateral lobes, $\mathrm{Mt}$ - metatarsus, PS - pseudoscape, $\mathrm{R}$ - radix, S stretcher, Th - thumb (= lateral extension of embolus), Ti - tibia, TmI - position of trichobothrium on tibia I.

Bolyphantes lagodekhensis (Tanasevitch, 1990), comb.n.

Figs $1-7$.

1987 Lepthyphantes sp. - Tanasevitch: 320, figs 36, 37, ㅇ.

1990 L. lagodekhensis Tanasevitch: 23, figs 9: 5, 6, ‥

MATERIAL. $1 \sigma^{7}, 7$ 우, GEORGIA, Caucasus Major, Khevsureti region, Kharoki valley, Mutso Mt. Ridge, above village Khone $\left(42.58733^{\circ} \mathrm{N}, 45.26528^{\circ} \mathrm{E}\right), \mathrm{W}$ of Mt. Tebulosmta, alpine 

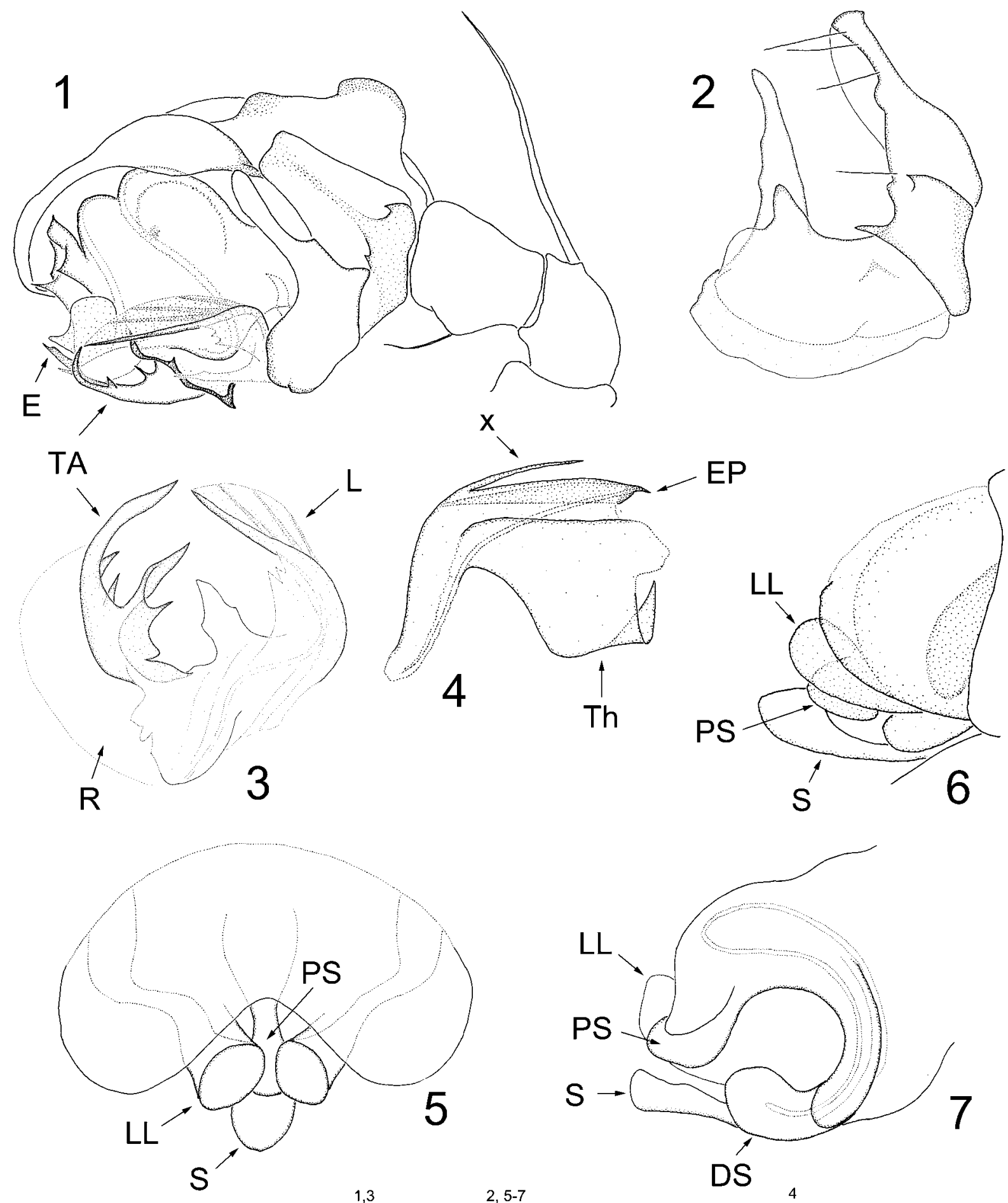

DS

4

Figs 1-7. Bolyphantes lagodekhensis (Tanasevitch, 1990): 1 - left palp; 2 - paracymbium; 3 - embolic division; 4 - embolus; 5 , 6 - epigyne, ventral and lateral views, respectively; 7 - epigyne, lateral view, left wall removed. Abbreviations: DS - distal part of scape, EP - embolus proper, L - lamella characteristica, LL - lateral lobes, PS - pseudoscape, R - radix, S — stretcher, TA terminal apophysis, Th - thumb.

Рис. 1-7. Bolyphantes lagodekhensis (Tanasevitch, 1990): 1 - левая пальпа; 2 - парацимбиум; 3 - эмболюсный отдел; 4 эмболюс; 5, 6 - эпигина, вид снизу и сбоку; 7 - эпигина, вид сбоку (левая боковая стенка удалена). 
Table 1. Length of leg segments and chaetotaxy in male of Bolyphantes lagodekhensis (Tanasevitch, 1990). Таблица 1. Длина члеников ног и хетотаксия самца Bolyphantes lagodekhensis (Tanasevitch, 1990).

\begin{tabular}{|c|c|c|c|c|c|}
\hline Legs & Femur & Patella & Tibia & Metatarsus & Tarsus \\
\hline Leg I: 5.33 & $\begin{array}{c}1.34 \\
0-1-0-0\end{array}$ & 0.31 & $\begin{array}{c}1.47 \\
2-0-0-1\end{array}$ & $\begin{array}{c}1.44 \\
2-0-0-2\end{array}$ & $\begin{array}{c}0.77 \\
0-0-0-0\end{array}$ \\
\hline Leg II: 4.43 & $\begin{array}{c}1.19 \\
0-0-0-0\end{array}$ & 0.28 & $\begin{array}{c}1.20 \\
2-0-1-1(2)\end{array}$ & $\begin{array}{c}1.12 \\
2-0-0-0\end{array}$ & $\begin{array}{c}0.64 \\
0-0-0-0\end{array}$ \\
\hline Leg III: 3.56 & $\begin{array}{c}1.00 \\
0-0-0-0\end{array}$ & 0.25 & $\begin{array}{c}0.87 \\
2-0(1)-1-1\end{array}$ & $\begin{array}{c}0.94 \\
1-0-0-0\end{array}$ & $\begin{array}{c}0.50 \\
0-0-0-0\end{array}$ \\
\hline Leg IV: 4.86 & $\begin{array}{c}1.41 \\
0-0-0-0\end{array}$ & 0.25 & $\begin{array}{c}1.25 \\
2-1-1-1\end{array}$ & $\begin{array}{c}1.29 \\
1-0-0-0\end{array}$ & $\begin{array}{c}0.66 \\
0-0-0-0\end{array}$ \\
\hline
\end{tabular}

and subnival zones, 2700-3200 $\mathrm{m}$ a.s.1., under plates of slate on a steep slope, 28.VII.2007, leg. S. Otto.

DESCRIPTION. Male (here described for the first time). Total length 2.31. Carapace 1.05 long, 0.83 wide, pale brown, with a grey median spot and a narrow margin tinged with black. Chelicerae 0.46 long, unmodified; anterior margin with two teeth, posterior unarmed. Stridulating files fine. Legs pale brown, without median bands. Length of leg segments shown in Table 1.

TmI 0.21. Palp (Figs 1-4): Patella with a thick, tapering and pointed spine, denticles absent. Cymbium with a ridge-shaped posterodorsal outgrowth. Posterolateral branch (sensu Helsdingen et al., 2001) of paracymbium rather thin and sclerotized. Paracymbium with two teeth in its proximal part. Terminal apophysis with several branches and tapering outgrowths. Lamella characteristica large and wide, consisting of a strong main branch and an attached sail-like membranous part. Serrate area of embolus with a long and narrow needleshaped outgrowth (x in Fig. 4). Thumb large, distally curved. Abdomen 1.23 long, 0.78 wide, dark grey, heart region pale, dorsal area flanked by pale paramedian spots connected to each other across dorsum with thin slanting bands behind pale region. Spinnerets dark grey.
Female. Total length $2.46 \mathrm{~mm}$. Carapace 0.88 long, 0.71 wide, light brown, with thin, dark fringe and thin fovea. Eyes with black fringes. Chelicerae 0.39 long, anterior margin with three teeth, posterior with four small teeth near base of fang. Stridulating files fine. Legs light brown, not annulated, in some specimens tibia with a thin proximal white band. Length of leg segments shown in Table 2.

TmI 0.21. Abdomen 1.65 long, 1.12 wide, coloration as in male, sometimes uniformly grey. Epigyne (Figs 5-7) with a short narrow pseudoscape. Lateral lobes of scape very long, their distal parts are partly covering of pseudoscape. Stretcher well developed, long and narrow.

TAXONOMIC REMARKS. According to the palp and epigyne conformation, this species definitely belongs to the genus Bolyphantes, and seems to be most similar to the South Siberian B. distichus (Tanasevitch, 1986) and B. distichoides Tanasevitch, 2000. The male of the species is clearly distinguishable from other congeners by the peculiar shape of the lamella characteristica, as well as by the presence of a long and narrow needle-shaped outgrowth on serrate area of the embolus. The female differs well by the very long lateral lobes which make the epigyne similar to those in the representatives of the genus Incestophantes Tanasevitch, 1992.

Table 2. Length of leg segments and chaetotaxy in female of Bolyphantes lagodekhensis (Tanasevitch, 1990). Таблица 2. Длина члеников ног и хетотаксия самки Bolyphantes lagodekhensis (Tanasevitch, 1990).

\begin{tabular}{|c|c|c|c|c|c|}
\hline Legs & Femur & Patella & Tibia & Metatarsus & Tarsus \\
\hline Leg I: 4.07 & $\begin{array}{c}1.05 \\
0-1-0-0\end{array}$ & 0.31 & $\begin{array}{c}1.08 \\
2-1-1-2(3)\end{array}$ & $\begin{array}{c}1.00 \\
2-0-0-0\end{array}$ & 0.63 \\
& 0.98 & 0.28 & 0.94 & $0.9-0$ \\
\hline Leg II: 3.68 & $0-0-0-0$ & & $2-1-1-2$ & $2-0-0-0$ & 0.57 \\
& 0.84 & 0.25 & 0.73 & 0.71 & 0.46 \\
\hline Leg III: 3.00 & $0-0-0-0$ & & $2-1-1-2$ & $1-0-0-0$ & $0-0-0-0$ \\
& 1.03 & 0.27 & 1.04 & 0.98 & 0.57 \\
\hline Leg IV: 3.95 & $0-0-0-0$ & & $2-1-1-1(2)$ & $1-0-0-0$ & $0-0-0-0$ \\
\hline
\end{tabular}




\section{References}

Helsdingen P.J. van, Thaler K., Deltshev C. 2001. The European species of Bolyphantes with an attempt of a phylogenetic analysis (Araneae Linyphiidae) // Mem. Soc. entomol. ital. Vol.80: $3-35$.

Saaristo M.I., Tanasevitch A.V. 1996. Redelimitation of the subfamily Micronetinae Hull, 1920 and the genus Lepthyphantes
Menge, 1866 with descriptions of some new genera // Ber. nat.-med. Verein Innsbruck. Bd.83. S.163-186.

Tanasevitch A.V. 1987. The linyphiid spiders of the Caucasus, USSR (Arachnida: Araneae: Linyphiidae) // Senckenberg. biol. Bd.67. H.4-6. S.297-383.

Tanasevitch A.V. 1990. [The spider family Linyphiidae in the fauna of the Caucasus (Arachnida, Aranei)] // Fauna nazemnykh bespozvonochnykh Kavkaza. Moscow: Nauka Publ. P.5114 [in Russian], 235 [English summary]. 